\title{
Ryssland utan Putin: friare, fredligare, rättvisare
}

\author{
Stig Fredrikson \\ Stockholm, Carlssons 2019 \\ 167 sider. 9789173319690
}

Omtalt av Martin Paulsen [seniorrådgiver, Diku, martpaulsen@hotmail.com]

Journalisten og forfattaren Stig Fredrikson er kanskje mest kjend som Aleksandr Solzjenitsyns kurer, men han har òg gitt ut fleire bøker om russisk politikk og samfunn. Dette er den andre boka hans som tek føre seg president Vladimir Putin, Oligarken och presidenten - Tvekampen mellan Chodorkovskij och Putin kom i 2015.

Ryssland utan Putin har sju kapittel og eit kort føreord. Sjølv om tittelen kanskje kan gi eit tvitydig inntrykk, etterlet ikkje innhaldslista, med dei gjennomgåande referansane til presidenten, noko tvil om kven som står i sentrum for handlinga. Boka opnar friskt med eit tydeleg nikk til Fredriksons gamle forfattarven. I kapittelet «En dag i Vladimir Vladimirovitjs liv» bruker Fredrikson førstehandsskildringar til å gi oss eit levande blikk inn i kvardagen til den russiske presidenten.

I dei neste fem kapitla forlét vi dette førstehandsperspektivet. Fredrikson refererer rapportar i internasjonale media og bøker om Putin for å gi lesaren eit innblikk i kven Putin er, kvar han kjem frå og kva som kjenneteiknar den makteliten han står i spissen for. Fokuset er tydeleg på dei negative sidene ved Putin-styret, og Fredrikson tar turen innom allereie velkjende tema som koplinga til KGB og skuldingar om korrupsjon.

I kapittel 2 spør Fredrikson kor lenge Putin vil verte sitjande som president. Svaret er så lenge han kan, fordi han er driven av makt og pengar. I kapittel 3 forklarar Fredrikson at det som forma Putin er karrieren i KGB: «För mig kommer han alltid att först och främst vara en KGB-mann» (s. 37). I det lange fjerde kapittelet greier han ut om kva innverking karrieren i KGB har hatt på Putin, og legg særleg vekt på at det har gjort han til ein notorisk løgnar. I kapittel 5 spør han seg kor rik Putin er, og i kapittel 6 ser han nærmare på det han kallar «AB Putin» - omtala som ei eksklusiv verksemd for krinsen rundt presidenten.

Mest interessant er det sjuande og lengste kapittelet i boka, med same namn som boka. Her kjem styrken til boka fram - at ho er fundert på ein tydeleg idé: Russland utan Putin ville ha vore eit friare, fredelegare og meir rettvist land. Dette polemiske utgangspunktet gir Fredrikson eit godt utgangspunkt for å argumentere 
for kva som er gale med Putins Russland. Det gir også teksten driv og rom for å sjå breitt på utviklinga i landet dei siste tiåra.

Samstundes har Fredrikson si tilnærming nokre grunnleggande svakheiter. For det første, så inneber fokuset på Putin ei veldig forenkling av realitetane i det politiske systemet i Russland. Nokre av dei kjeldene Fredrikson refererer til, som til dømes Mikhail Zygar si bok Mennene $i \mathrm{Kreml}$, understrekar jo nettopp samspelet i den politiske eliten i Russland. Fredrikson sitt einsidige fokus på Putin si rolle bidrar snarare til å hindre, enn til å fremje forståing av utviklinga i Russland.

For det andre, så er boka dominert av liberale, vestvenlege kjelder. Intervjuobjekta er kunnskapsrike menneske som gjer ein viktig jobb for å utvikle Russland i ei demokratisk retning. Likevel blir det ei svakheit for boka når deira perspektiv på utviklinga i landet ikkje blir utfordra av aktørar som har andre standpunkt.

Det største problemet er likevel at Fredrikson ikkje er open for å vurdere om tesen hans kan vere feil. Kan det vere slik at eit Russland utan Putin ikkje ville bli eit friare, fredlegare og meir rettferdig land? Eit slikt scenario teiknast opp av Anna Dobrovolskaja, eit av Fredrikson sine intervjuobjekt i boka og leiar for Moskvakontoret av Memorial. Ho ser for seg to moglege scenario dersom Putin skulle forsvinne; eit godt og eit dårleg. Det gode inneber utvikling av sjølvstendige institusjonar som er uavhengige av presidenten, det dårlege inneber ei tilspissing med maktkampar mellom ulike klanar. Fredrikson gir slepp på ein gylden moglegheit til å løfte boka når han ikkje følgjer opp det dårlege scenarioet til Dobrovolskaja. 